\section{Norway wolf cull will hit genetic diversity}

Norway's regional management authorities have approved plans to cull up to $70 \%$ of its grey wolves (Canis lupus). Because the current population consists of just 65-68 individuals, of which only 21 are thought to be sexually mature (see go.nature.com/2euyixy), this cull and the subsequent loss of genetic material would seem to be a significant misstep for ensuring the wolf's persistence in Norway.

Preserving genetic variation is crucial for the long-term survival of populations in fragmented landscapes. The genetic diversity of these wolves is already low because the entire population is descended from just a few individuals (C. Vilà et al. Proc. Biol. Sci. 270, 91-97; 2003). Their small population size and founding history mean that they need genetic input from immigrant wolves from Sweden, Finland and Russia to survive. Otherwise, they face the same fate as the well-studied Isle Royale wolf population in the United States (see Nature 520, 415; 2015).

Livestock protection is the Norwegian government's main justification for the cull, although less than $9 \%$ of Norway's sheep are taken by wolves (data from go.nature.com/2eemukj). The government is ignoring wellestablished scientific practices for managing a critically threatened species, as well as overriding its commitment to the Bern Convention, which lists the wolf as a strictly protected species. Elina Immonen Uppsala University, Sweden.

Arild Husby University of

Helsinki, Finland. arild.husby@helsinki.fi

\section{Inequality: need for data on all nations}

Inequality studies need to be more representative - the countries that suffer the most from inequality are also those that we know the least about (see
Nature 537, 466-470; 2016).

Between 1994 and 2013, North

America and western Europe together accounted for $80 \%$ of all publications on inequalities and social justice (ISSC, IDS and UNESCO World Social Science Report; UNESCO, 2016). The number of publications and data on these themes are very low from sub-Saharan Africa, south and east Asia, former eastern-bloc countries and the Arab world. This imbalance in our knowledge about inequality diminishes our global capacity to address it. Mathieu Denis International Social Science Council, Paris, France.

Melissa Leach Institute of Development Studies, University of Sussex, Brighton, UK. mathieu@worldsocialscience.org

\section{Inequality: span the global divide}

National initiatives need to correct injustices related to class, inequality and salaries among scientists (see Nature 537, 466-470; 2016). However, such measures may serve to reinforce the global north-south divide in research if, perhaps inevitably, they are more prevalent in higher-income countries.

The domination of the scientific agenda and literature by northern over southern researchers has serious implications for how science is designed and produced, undermining its salience, credibility and legitimacy — and therefore its influence on policy development and implementation (see D. W. Cash et al. Proc. Natl Acad. Sci. USA 100, 8086-8091; 2003).

We suggest that the world's many transboundary issues such as climate change, poverty, human migration, public health and biodiversity decline - call for a more comprehensive, global approach. This should span the north-south divide by addressing the underlying issues and their consequences (see, for example, M. Blicharska et al.
Nature Clim. Change; in the press). Richard J. Smithers Ricardo Energy \& Environment, Harwell, $U K$.

Malgorzata Blicharska Uppsala University, Uppsala, Sweden. José María Gutiérrez University of Costa Rica, San José, Costa Rica. richard.smithers@ricardo.com

\section{Protect aquaculture from ship pathogens}

Aquaculture is the world's fastestgrowing food-production sector and a crucial contributor to the United Nations' Sustainable Development Goals. As a group of scientists, ocean-policy experts, aquaculture professionals and technical consultants from international organizations, we argue that, despite recent legislation, fish farms may still be at risk from pathogens in ballast water discharged from ships.

The International Convention for the Control and Management of Ships' Ballast Water and Sediments (go.nature. com/2evuskh) will come into force in September 2017. This will reduce the risks of transfer of organisms larger than 10 micrometres and of bacteria that are harmful to humans, including Vibrio cholerae,

Escherichia coli and Enterococcus species. However, the convention does not mention any other aquatic bacteria or viruses that could cause epidemics in the US\$160-billion aquaculture industry and threaten food security.

We suggest using a combination of molecular tools, experimental investigation, monitoring data and operational models to evaluate the risks and possible impacts on local aquaculture farms of how, when and where ships discharge ballast water. The findings should be presented to UN-OCEANS (www.unoceans.org) and the Joint Group of Experts on the Scientific Aspects of Marine Environmental Protection (www.gesamp.org) to support existing regulatory frameworks. Guillaume Drillet ${ }^{\star} D H I$,

Singapore.

gdr@dhigroup.com

${ }^{\star}$ On behalf of 11 correspondents (see go.nature.com/2en $2 b t v$ for full list).

\section{Small data call for big ideas}

Despite the meteoric rise in big-data approaches, funders also need to recognize that some of the most pressing problems must instead rely on the intelligent use of small data sets.

Value-of-information analysis can evaluate whether bigdata collection is worthwhile (R. Schlaifer and H. Raiffa Applied Statistical Decision Theory; Clinton, 1961). Collecting big monitoring data for threatened or invasive species, for instance, risks delaying decisions on protective measures. It might be better to fund direct action, as for killer whales in the Georgia basin (E. McDonaldMadden et al. Trends Ecol. Evol. 25, 547-550; 2010).

Urgent decisions may be necessary when information is sparse. In agricultural systems, a fast response to a new pest or disease outbreak can make the difference between eradication and decades of costly quarantine programmes. In ecology, population sizes and detectability are often too low to create big data sets. In health, defence and social sciences, collecting big data risks violating human ethics.

Where data are limited, scientific solutions underpinned by strategies such as adaptive management can optimize decision making (I. Chadès et al. Theor. Ecol. http://doi.org/br9s; 2016). Artificial intelligence, for example, can inform adaptation strategies for sea-level rise to protect migratory shorebirds worldwide (S. Nicol et al. Proc. R. Soc. B 282, 20142984; 2015). Iadine Chadès, Sam Nicol CSIRO, Dutton Park, Queensland, Australia. iadine.chades@csiro.au 